\title{
Kök hücreler kanser hücrelerinin mikroçevresindeki sitokin yanıtlarını etkiler: Meme kanseri ve dental pulpa kök hücreleri arasındaki etkileşim
}

Stem cells affect cytokine responses in the microenvironment of tumor cells: Interaction between breast cancer and dental pulp stem cells

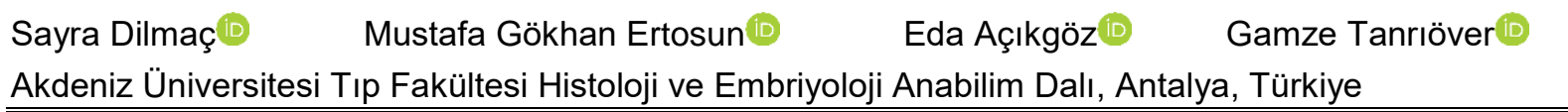

\section{ÖZ}

Amaç: Tümör ve mikroçevresinde bulunan hücreler birbirleri ile yakından ilişkilidir ve sürekli etkileşim halindedirler. Bu hücreler arasındaki karşılıklı etkileşim, tümörün gelişmesi ve metastazında rol oynayan sitokin yanıtlarını şekillendirir. Kök hücreler ile bunların nişleri arasındaki etkileşimlerin de; tümör hücrelerine benzer şekilde karşılıklı olduğu bilinmektedir. Dönüştürücü Büyüme Faktörü Beta1 ve Büyüme/farklılaşma faktörü15, tümör mikroçevresi üzerinde çift yönlü etkileri olan sitokinlerdir. Çalışmamızda, tümör hücreleri ve kök hücrelerin karşılıklı etkileşimlerinin mikroçevrelerindeki sitokin yanıtlarına olan etkilerini araştırmayı amaçladık.

Gereç ve Yöntem: Bu çalışmada ko-kültür deneyleri için Dental pulpa kök hücreleri ile MDA-MB-231 meme kanseri hücreleri kullanılmıştır. MDA-MB-231 ve Dental Pulpa Kök Hücreleri hem bireysel hem de birlikte farklı kombinasyonlarla kültüre edildi ve koşullu medyumları toplandı. Toplanan koşullu medyumlarda Dönüştürücü Büyüme Faktörü Beta1 ve Büyüme/farklılaşma faktörü15 sitokin seviyeleri ELISA yöntemi ile değerlendirildi.

Bulgular: MDA-MB-231 hücrelerinin koşullu medyumları ile inkübe edilen Dental pulpa kök hücre medyumunda Dönüştürücü Büyüme Faktörü Beta1 ve Büyüme/farklılaşma faktörü15 ekspresyonlarının arttığı ancak, tek tek hücre hatlarından alınan medyumlarda bu sitokin seviyelerinde fark olmadığı görüldü. Seçilen bu sitokin yanıtlarının artması tümör hücrelerinin metastaz potansiyellerini etkileyeceğinden önem içermektedir.

Sonuç: Tümör hücreleri ve kök hücreler arasındaki karşılıklı konuşma, tümör mikroçevresindeki sitokinlerin yanıtlarını değiştirir ve tümörün metastaz potansiyelini etkileyebilir. Dolayısıyla çalışmamız tümör mikroçevresinin, tümörün gelecek yanıtlarında önemini vurgulayan bir çalışma olma nitelinde olup bu yönüyle literatüre katkı sağlayacaktır.

Anahtar Sözcükler: Üçlü negatif meme kanseri, dental pulpa kök hücreleri, koşullu medyum, dönüştürücü büyüme faktörü beta1, büyüme/farklılaşma faktörü15.

\begin{abstract}
Aim: Tumor and surrounding microenvironment cells are closely related and interact constantly. The mutual communication between these cells may affect some factors such as cytokines that involved in tumor progression and metastasis. In the interactions between stem cells and their niches; It is known to be reciprocal similar to tumor cells. Transforming Growth Factor Beta1 and Growth Differentiation Factor15 are cytokines which have dual effects on the tumor microenvironment. In our study, we aimed to investigate the effects of interaction of tumor cells and stem cells on cytokine responses in their microenvironment.
\end{abstract}

Sorumlu yazar: Gamze Tanrı̈ver

Akdeniz Üniversitesi Tıp Fakültesi Histoloji ve Embriyoloji

Anabilim Dalı, Antalya, Türkiye

E-posta: gamzetanriover@akdeniz.edu.tr

Başvuru tarihi: 13.02.2021 Kabul tarihi: 26.02.2021 
Materials and Methods: Dental pulp stem cells and MDA-MB-231 cells were used in co-culture experiments in this study. MDA-MB-231 and Dental Pulp Stem Cells were cultured both individually and together in different combinations and their conditional media were collected. Transforming Growth Factor Beta1 and Growth Differentiation Factor15 cytokine levels in conditional media were determined by using ELISA.

Results: Expression of Transforming Growth Factor Beta1 and Growth Differentiation Factor15 increased in Dental Pulp Stem Cell medium incubated with conditional media from MDA-MB-231 cells, but there was no difference in these cytokine levels in media taken from individual cell lines. Increasing these selected cytokine responses will affect the metastasis potential of tumor cells.

Conclusion: We observed that cross-talks between tumor cells and stem cells alters the responses of cytokines in the tumor microenvironment and affects tumor progression. Therefore, our study emphasizes the importance of the tumor microenvironment in tumor responses, and may contribute to the new perspectives in this respect.

Keywords: Triple negative breast cancer, dental pulp stem cells, conditional media, transforming growth factor beta1, growth differentiation factor15.

\section{Gíriş}

Meme kanseri, kadınlarda sık karşılaşılan kanser türlerinden biridir ve tüm dünyadaki kadın kanserlerinin \%25'ini oluşturmaktadır $(1,2)$. Üçlü Negatif Meme Kanseri (ÜNMK), Östrojen (ÖR) ve progesteron (PR) hormonları ve HER2 (insan epidermal büyüme faktörü reseptörü 2) yüzey reseptörlerinin hiçbirini hücre yüzeyinde bulundurmayan meme kanseri alt tipi olarak tanımlanmaktadır. Tüm meme kanserlerinin \%15 ila \% 20'sini oluşturan ÜNMK, daha sık genç hastaları etkilemekte ve sıklıkla kötü prognoza sahip olarak bilinmektedir (3). Üçlü Negatif Meme Kanseri, hormon bağımlı tedavi seçeneklerine dirençli olması sebebiyle tedaviye en az yanıt veren meme kanseri tipidir (4).

Tümör mikroçevresi karmaşık bir popülasyondur. Tümör mikroçevresinde hücre dışı matriksin (HDM) yanı sıra miyofibroblastlar ve fibroblastlar, yağ hücreleri, immün hücreler, kan ve lenfatik damarlar gibi hücresel elemanlar yer almaktadır (5). Tümör hücreleri ve tümör mikroçevresi arasındaki iletişim tümör gelişiminde oldukça önemli bir unsurdur. In vivo tümör gelişiminde mikroçevrenin sağlıklı olmadığı durumlarda invazyon ve metastazın daha kolay şekilde gerçekleştiği bilinmektedir (6). Buna ek olarak tümör hücrelerinin mikroçevreleri ile olan ilişkileri henüz net olarak tanımlanabilmiş değildir.

Tümör gelişimi sırasında tümör mikroçevresinde kronik inflamasyon meydana gelmektedir. Bu durumda bu bölgede bulunan hücreler tarafından çeşitli sitokinler salgılanmaktadır $(7,8)$. Tümör mikroçevresindeki hücrelerden salgılanan bu sitokinler, tümöre karşı bir savunma yaratabileceği gibi; tümörle ilerleyen immün yanıta da destek olup tümör ilerlemesini teşvik edebilmektedirler (9). Örneğin; TGF $\beta 1$ (Dönüştürücü Büyüme Faktörü $\beta 1$ ); sitokin yanıtı oluşmasını sağlayarak regülatör $T$ hücrelerinin (TReg) ve Myeloid Kökenli Baskılayıcı Hücrelerin (MDSC) aktive edilmesi gibi tümör gelişimi ve metastazında aktif olarak görev almaktadırlar (10).

TGF $\beta$ süper ailesi, embriyonik gelişim sırasında ve yetişkinlerde çeşitli biyolojik süreçlerin düzenlenmesinde kritik rol oynayan 60'dan fazla proteinden oluşan büyük bir ailedir. Özellikle, TGF $\beta$ alt ailesinin memelilerde en iyi çalışılan izoformu olan TGF $\beta 1$ 'in hücre proliferasyonu, farklılaşması, adezyon, migrasyon, anjiyogenez, apoptoz ve immün yanıt üzerinde düzenleyici rolleri olduğu bilinmektedir (11). TGF $\beta 1$ genindeki polimorfizmin TGF'in serum seviyesinin artmasına sebep olduğu ve bu durumun da meme kanseri riskini arttırdığı bilinmektedir (12, 13).

Büyüme/farklılaşma faktörü15 (GDF15), ya da diğer bilinen adıyla MIC-1 (Makrofaj İnhibitör Sitokin 1) TGF- $\beta$ üst ailesinin bir üyesi olarak keşfedilmiştir (14). GDF15'in, servikal kanser, multipl miyelom ve kolon kanseri gibi kanserlerin gelişimi ile ilişkili olduğu (15-17); ayrıca kolon, prostat ve akciğer kanseri gibi birçok kanser türünde de metastazı desteklediği bilinmektedir $(15,18)$. Son yıllarda GDF15'in meme kanseri hücrelerinde metastazla ilişkilendirildiği belirtilmektedir (19).

Kök hücreler; süresiz olarak kendini yenileme, tek hücreden türetilen klonal hücre popülasyonları 
oluşturma ve çeşitli hücre tiplerine farklılaşma yetenekleri ile tanımlanmaktadırlar (20). Kök hücreler genel olarak "embriyonik kök hücreler" $(\mathrm{EKH})$ veya "somatik kök hücreler" (SKH) olarak sınıflandırılabilir. SKH'ler, genellikle pluripotent özellikte olan nöral kök hücreler (NKH), mezenkimal kök hücreler (MKH), hematopoietik kök hücreler $(\mathrm{HKH})$, endotel progenitör hücreler (EPKH)'den oluşan belirli bir soy ile bir diğer hücre tipine farklılaşabilen yetişkin kök hücreler olarak da bilinir (21). Kök hücreler salgıladıkları sitokin ve büyüme faktörleri ile birçok fonksiyonu düzenleyebilme yeteneğine sahiptirler. Örneğin Adiposit Kökenli Kök Hücreler (AKKH) insülin benzeri büyüme faktörü (IGF), hepatosit büyüme faktörü (HGF), VEGF (Vasküler Endotelyal Büyüme Faktörü), IL-8 ve TGF $\beta$ dâhil olmak üzere birçok faktör üretebilir ve epitelyalmezenkimal geçişi (EMG) indükleyebilir, hücreleri invazyon ve metastaza teşvik ederler (22-27). Bununla birlikte, günümüzde, kök hücrelerin tümör-stromal etkileşiminin tümör mikroçevresine salgılanan faktörler tarafından nasıl yönlendirildiği belirsizliğini korumaktadır.

In vivo tümör gelişiminde tümör hücrelerinin mikroçevrede bulunan diğer hücrelerle etkileşimi kolay sağlanırken in vitro deney modellerinde bu şekilde bir etkileşim görülmemektedir. Çünkü in vitro kültür ortamlarında tümör hücreleri çoğunlukla tek başlarına büyütülerek deney modelleri tasarlanmaktadır. Biz çalışmamızda tümör hücrelerinin bulunduğu kültür tabaklarına ayrı bir hücre grubu ekleyerek sadece bu iki hücre tipi arasındaki etkileşimi değerlendirmeyi planladık. Çalışmamızda insan üçlü negatif meme kanseri hücre hattı olan MDA-MB-231 hücreleri ile mezenkimal kök hücre grubuna dâhil bir kök hücre tipi olan insan dental pulpa kök hücrelerini (DPKH) birlikte kültüre edilerek bu iki hücre arasındaki karşılıklı etkileşimin TGF $\beta 1$ ve GDF15 seviyelerinin değişimlerini nasıl etkileyeceğinin değerlendirilmesi amaçlandı.

\section{GEREÇ ve YÖNTEM}

\section{MDA-MB-231 ve DPKH Hücrelerinin Çoğaltılması}

Çalışmamızda, ÜNMK hücre hattı olan MDA-MB231 ve DPKH kullanılmıştır. Bu iki hücre hattı ile ko-kültür deneyleri için koşullu medyumlar ve normal hücre medyumları elde edildi.

MDA-MB-231 ve DPKH hücreleri \%10'luk Fötal Bovin Serum (FBS) (Gibco; \#10270, MA, USA) ve \%1'lik Penisilin-Streptomycin (PS) (Thermo
Fisher, \#15140122, MA, USA) ile desteklenmiş Dulbecco's modified eagle medyumunda (DMEM F-12) (Gibco; \#11320-074, MA, USA), $37^{\circ} \mathrm{C}$ sıcaklık ve $\% 5 \quad \mathrm{CO}_{2}$ koşullarına sabitlenmiş inkübatörde çoğaltıldı. Hücreler \%80 konfluensiye ulaştıktan sonra medyumları uzaklaştırıldı ve ardından hücrelerin kültür kabından ayrılması için Tripsin-EDTA (Gibco; 25200-056, MA, USA) ile muamele edildi.

Ko-kültür deneyleri için MDA-MB-231 ve DPKH hem ayrı ayrı hem de aynı anda 6 kuyucuklu kültür tabaklarına ekildi. Ayrıca, ayrı ayrı ekilen MDA-MB-231 ve DPKH'nin medyumları toplanıp birbirleriyle kültüre edilerek ortamdaki hücrelerin sitokin yanıtlarını nasıl değiştireceği de incelendi.

\section{MDA-MB-231 ve DPKH'nin Ekilmesi ve Koşullu Medyumların Eldesi}

Santrifüj edilip taze medyuma alınan hücreler sayılarak MDA-MB-231 ve DPKH'nin her birinden 50.000 hücre olacak şekilde 6 kuyucuklu kültür tabaklarına (Corning; \#3516, NY, USA) aşağıda ifade edildiği biçimde ekildi (Şekil-1).

1 numaralı kuyucuğa; 50.000 adet MDA-MB231 hücresi ekildi. 72 . saatin sonunda MDA-MB231 hücrelerinin medyumları toplandı.

2 numaralı kuyucuğa; 50.000 adet DPKH hücresi ekildi ve 72 . saatin sonunda DPKH'nin medyumları toplandı.

3 numaralı kuyucuğa; 50.000 adet MDA-MB231 hücresi ekildi, hemen ardından bu hücrelerin üzerlerine 50.000 adet $\mathrm{DPKH}$ ekildi. 72. saatin sonunda MDA-MB-231 ve DPKH'lerinin ortak koşullu medyumları toplandı.

4 numaralı kuyucuğa; 1. gün 50.000 adet MDAMB-231 hücresi ekildi. 72 . saatin sonunda hücrelerin üzerindeki medyum toplandı ve DPKH'nin üzerine eklendi.

5 numaralı kuyucuğa; 4 numaralı kuyucukta yapıldığı gibi 1. gün 50.000 adet DPKH ekildi. 72 . saatin sonunda hücrelerin üzerindeki medyum toplandı ve MDA-MB-231 hücrelerinin üzerine eklendi. Aynı zamanda yan kuyucukta bulunan MDA-MB-231 hücrelerinin üzerinden alınan medyum da DPKH hücrelerinin üzerine eklendi.

4 ve 5 numaralı kuyucuklar medyum değişikliklerinden sonra yeni medyumları ile 72 saat inkübe edildi ve 72 . saatin sonunda ortak koşullu medyumları toplandı. Toplanan koşullu medyumlar $-20^{\circ} \mathrm{C}$ 'de saklandı. 


\section{Koşullu Medyumlardaki Sitokin Seviyelerinin ELISA Metodu ile Belirlenmesi}

Şekilde belirtildiği haliyle farklı koşullar oluşturularak toplanan MDA-MB-231 ve DPKH'ne ait medyumlarda multifonksiyonel bir sitokin olan TGF $\beta 1$ (Thermo Fisher; \#BMS249/4, MA, USA) ve TGF $\beta$ ailesi üyesi inflamatuvar bir sitokin olan GDF15 (RayBioTech; \#ELH-GDF15-001, GA, USA) seviyeleri ELISA yöntemi ile tespit edildi.

Yakalama antikoru ile kaplanmış olan kitlere, firmanın önerdiği şekilde hazırlanan bloklama solüsyonu eklenerek 1 saat oda Isısında bekletildi. Ardından kuyucuklar yıkanarak ve kitte önerildiği şekilde hazırlanan standartlar ve koşullu medyum örnekleri $100 \mu \mathrm{L}$ olacak şekilde kuyucuklara yüklendi. 2 saat oda ısısında inkübe edildikten sonra kuyucuklar yıkandı ve tespit etme (detection) antikoru ile oda Isısında 1,5 saat inkübe edildi. Ardından yeniden yıkama yapıldı ve HRP-enzim çözeltisi eklenerek $30 \mathrm{dk}$ oda ısısında inkübe edildi. Substrat solüsyonu hazırlanarak kuyucuklara eklendi ve oda ısısında 60 dk karanlıkta bekletildi. Kuyucuklara durdurma solüsyonu eklenerek reaksiyon durduruldu ve ELISA okuyucu yardımıyla TGF $\beta 1$ için $450 \mathrm{~nm}$ ve GDF15 için 45nm dalga boylarında okutuldu ve elde edilen değerler KC junior (Biotek Instruments; NY, USA) programı ile hesaplandı ve Graph Pad Prism (Graph Pad Software; CA, USA) programında da istatistiksel olarak değerlendirildi.

\section{BULGULAR}

\section{TGF $\beta 1$ Sitokin Seviyesinin Hücrelere Göre Koşullu Medyumlardaki Değişimi}

MDA-MB-231 ve DPKH'lerinin ayrı ayrı ve birlikte ekilmeleri; ayrıca MDA-MB-231 ve DPKH'lerinin koşullu medyumlarının birbirleri ile değiştirilmesinin ardından toplanan yeni koşullu medyumlarda TGF $\beta 1$ sitokin seviyesinin değişimi değerlendirildi. Elde ettiğimiz sonuçlara göre, MDA-MB-231 hücrelerinin medyumunun DPKH üzerine eklenmesinin TGF $\beta 1$ sitokinin salınımını anlamlı olarak arttırdığı görüldü (Şekil-2) (a; $p=0,0034)$. Buna ek olarak, DPKH hücrelerinin üzerine MDA-MB-231 hücrelerinden elde edilen medyumun eklenmesinin, bu hücrelerin aynı anda ekilmesine kıyasla TGF $\beta 1$ seviyesini arttırdığı da görüldü (Şekil-2) (b; $p=0,02)$.

Dental pulpa kök hücrelerinin medyumunun, MDA-MB-231 hücrelerinin üzerine eklenmesinin TGF $\beta 1$ seviyesini arttırdığı ancak bu artışın MDA-
MB-231'lerinin kendi medyumuna kıyasla anlamlı olmadığı görüldü (Şekil-2) $(p=0,3642)$. Ayrıca, MDA-MB-231 hücreleri ve DPKH'lerinin kendi medyumlarında TGF $\beta 1$ sitokinin salınımı, MDAMB-231 ve DPKH'lerin aynı anda ekilmesinden elde edilen medyuma kıyasla değişmemektedir (Şekil-2).

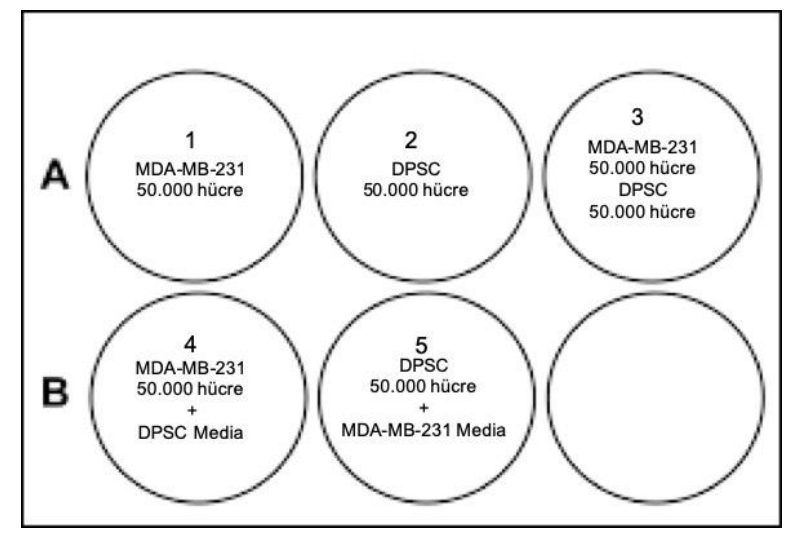

Şekil-1. Hücrelerin kuyucuklara ekilme şeması.

\section{TGF $\beta 1$}

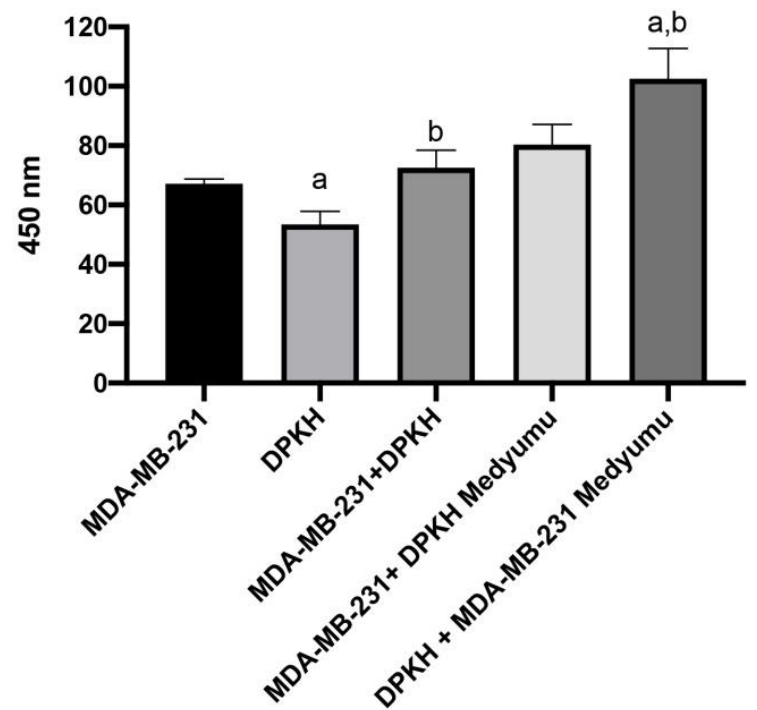

Şekil-2. MDA-MB-231 ve DPKH'lerinin kendi medyumlarında, birlikte kültüre edilmeleri (co-culture) durumundaki medyumda ve medyumlarının değiştirilmesi TGF $\beta 1$ sitokin salınımını gösteren grafik görülmektedir. Buna göre; kök hücreler (DPKH) üzerine eklenen tümör hücrelerinin (MDA-MB-231) medyumunun TGF $\beta 1$ sitokin salınımını anlamlı olarak etkilediği görülmektedir (a; $p=0,0034 ; b ; p=0,02)$. 


\section{GDF15 Sitokin Seviyesinin Hücrelere Göre Koşullu Medyumlardaki Değişimi}

MDA-MB-231 ve DPKH'lerinden elde edilen koşullu medyumlarda inflamatuvar sitokin GDF15 seviyesi değişimi incelendiğinde; MDA-MB-231 hücrelerinden elde edilen koşullu medyumunun DPKH'lerinin GDF15 salgılamasını yüksek düzeyde arttırdığı tespit edildi (Şekil-3) (a; $p=0,0002)$. MDA-MB-231 hücrelerinin medyumunda, hücreler DPKH'leri ile kültüre edildiğinde GDF15 sitokin seviyesi belirgin derecede düşükken; DPKH'lerin üzerine eklendiğinde anlamlı olarak artması oldukça önemli bir bulgudur (Şekil-3) (b; $p=0,0001)$. Bu durum, MDA-MB-231 hücrelerinin medyuma salgıladıkları faktörlerin DPKH'lerini etkileyerek GDF15 salınımını arttırdığını doğrulamaktadır.

Elde ettiğimiz sonuçlar; tümör hücrelerinin medyumlarına salgıladıkları faktörlerin çok önemli bir içeriğe sahip olduğunu ve tümörün gelişmesini tetiklediği bilgisinden yola çıkarak; ortamda bulunan kök hücreleri de benzer şekilde etkileyerek sitokin salınımını arttırdığını göstermektedir.

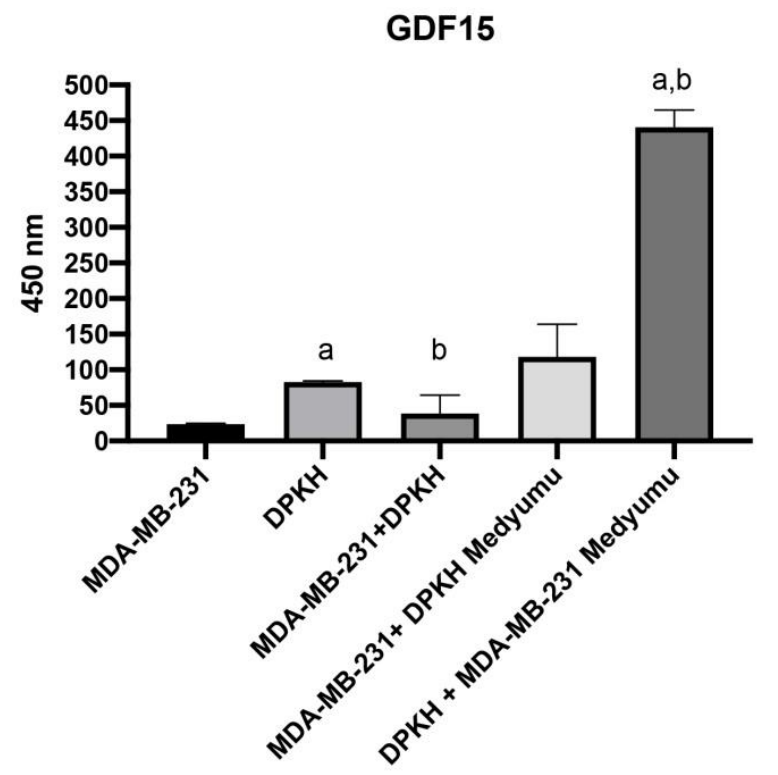

Şekil-3. MDA-MB-231 ve DPKH'lerinin kendi medyumlarında, birlikte kültüre edilmeleri (co-culture) durumundaki medyumda ve medyumlarının değiştirilmesi sonrasında GDF15 sitokin salınımını gösteren grafik görülmektedir. Buna göre MDA-MB-231 hücrelerinin medyumunun DPKH'leri üzerine eklenmesinin GDF15 sitokin salınımını anlamlı olarak etkilediği görülmektedir ( $a ; p=0,0002 ; b ; p=0,0001)$.

\section{TARTIŞMA}

Meme kanseri, kadınlarda en sık görülen kanser tipi olarak bilinmektedir. Meme kanseri alt tiplerine göre farklılık göstermekte ve bu farklılıklar kanserin ilerleme seyrini etkilemektedir (28). Meme kanseri, heterojen hücrelerden oluşan bir hastalıktır. Meme kanserinin alt tipleri, hormon reseptörlerinin immünohistokimyasal ekspresyonuna ve HER2 yokluğu veya aşırı ekspresyonuna göre tanımlanmaktadır. $\mathrm{Bu}$ histopatolojik farklılaşma, tümör heterojenliğini doğrulayan ve bu alt tipleri tamamen farklı kanser tipleri olarak değerlendirme ve tedavi etme intiyacını doğurmaktadır (29).

Üçlü Negatif Meme Kanseri genellikle yüksek dereceli invaziv duktal karsinom şeklinde görülür ve genellikle uzak metastazlarla daha yüksek ve erken nüks oranına sahiptir. Diğer meme kanseri alt tiplerine kıyasla daha kötü prognozla ilişkilendirilmiştir. Tümör biyolojisini aydınlatmak için ÜNMK'leri ile yapılan çok sayıda çalışmaya rağmen, klinik sonuçlar ne yazık ki tatmin edici değildir (29). Bu nedenle bu alanda daha çok çalışmanın yapılmasına intiyaç duyulmaktadır.

Tümörlerin sadece neoplastik hücrelerden oluşmadığı, farklılaşmış bir çevreye sahip olduğu bilinmektedir. Tümör mikroçevresi, tümörün gelişimi, büyümesi ve yayılması için kritik bir unsur ve tedaviye yardımcı bir yanıt parametresi olarak kabul edilmektedir $(30,31)$. Meme kanseri mikroçevresi, lokal (tümör içi), bölgesel (memede) ve uzak (metastatik) seviyelerde; her biri fibroblastlar, lökositler, adipositler, miyoepitelyal ve endotelyal hücreler gibi çoklu hücre tiplerini kapsayan heterojen hücrelerden oluşan bir ortamdır. Ayrıca; hücre dışı matriks, çözünür faktörler (örneğin sitokinler, hormonlar, büyüme faktörleri ve enzimler) gibi bileşenleri de içermektedir (32). Epitelyal ve stromal hücreler arasındaki karşılıklı ilişki, meme bezinin normal gelişimi ve farklılaşması için önemlidir. Fizyolojik stroma, epitelyal polariteyi korur; kontrolsüz hücre büyümesini ve neoplastik dönüşümü engeller (33).

Tümör mikroçevresinde inflamasyon ile ilişkili hücreler bulunmaktadır, bunlar başlıca makrofajlar, dendritik hücreler, miyeloid kökenli baskılayıcı hücreler, $T$ hücreleri, mast hücreleri ve doğal öldürücü (NK) hücrelerdir (34). Yapılan çalışmalar, immün sistemin tümörogenez üzerinde hem olumlu hem de olumsuz etkileri olduğunu ve inflamatuvar mikroçevrenin tümörler için önemli bir bileşen olarak rol oynadığı görüşünü desteklemektedir (35-37). Bununla 
birlikte, inflamasyonun tümör gelişimi ve diğer hastalıklardaki rolü, büyük ölçüde sitokinlerin salgılanmasına ve mikroçevredeki diğer hücrelerle kurdukları etkileşime bağlıdır (37).

Tümör mikroçevresinde oluşan inflamatuvar yanıt, makrofajlar, miyeloid kökenli baskılayıcı hücreler ve mezenkimal kök hücreler gibi hücre tiplerinin bu alanda toplanmasını sağlamaktadır (38). Tümör hücreleri ve bunları çevreleyen stroma hücreleri arasındaki karşılıklı ilişki, tümör ilerlemesini teşvik eder ve invaziv tümör hücresi için uygun olan dinamik bir hücre dışı matriks oluşturur (39). MKH'ler, başlangıçta üç ana soya (osteoblastlar, kondrositler ve adipositler) farklılaşma kapasitesine sahip olduğu bilinen çok potansiyelli kök hücrelerdir (40). Genellikle üç soya farklılaşma kapasiteleri ve CD73, CD105 ve CD90 yüzey belirteçlerinin pozitifliği ile karakterizedir (41). Kemik iliği, yağ dokusu ve diş pulpasından elde edilebilirler $(40,42,43)$. Ayrıca dolaşımda bulunurlar ve inflamatuvar bölgelere yöneldikleri bilinmektedir (44).

Mezenkimal kök hücreler arasında, dental pulpa kök hücreleri benzersiz bir yetişkin kök hücre kaynağı olarak tanımlanmıştır (42). Dental pulpa kök hücreleri, kök hücre özelliklerini ve hücre yüzey fenotipini hücre kültürü şartlarında uzun süre korumaktadırlar (45). Literatürde DPKH'lerinden çeşitli büyüme faktörleri ve sitokin salgılandığı bildirilmiştir. Anjiyopoietin, VEGF ve İnsülin benzeri büyüme faktörü bağlayıcı protein 3 (IGFBP-3) dahil olmak üzere anjiyojenik faktörler, anjiyogenezi teşvik edebilen DPKH tarafından salgılanabilmektedir (46). Buna ek olarak; DPKH'lerinin Kemik Morfogenik Protein 2 (BMP2), VEGF, TGF- $\beta 1$ ve Fibroblast Büyüme Faktörü 2 (FGF-2) salgıladıkları da bilinmektedir (47). Mezenkimal kök hücrelerin tümör büyümesi ve metastaz sürecindeki düzenleyici rolü bilinmesine rağmen, DPKH'leri ve tümör hücresi arasındaki etkileşimleri henüz yeterince tanımlanmamıştır.

TGF-süper ailesi, hücre büyümesini ve farklılaşmasını düzenlemektedir. Memelilerde TGF $\beta 1$, TGF $\beta 2$, TGF $\beta 3$ ve TGF $\beta 1 \beta 2$ dahil olmak üzere en az dört TGF $\beta$ alt tipi bulunmuştur; ancak, TGF $\beta 1$ en çok çalışılan sitokindir. TGF $\beta 1$ 'in tümör ilerlemesindeki rolünün, tümör aşamasına bağlı olarak çok yönlü olduğu gösterilmiştir. Bu sitokin, bir büyüme inhibitörü görevi görmektedir. Epitel hücre döngüsünün ilerlemesini engellediği ve apoptozu desteklediği gösterilmiştir ki, bunlar birlikte karsinom başlangıcı ve ilerlemesi sırasında tümör baskılayıcı rolü olduğunu düşündürmektedir (4850). Ayrıca, TGF $\beta 1$ 'in epitelyal-mezenkimal geçişi indükleme ve geliştirme yeteneği, TGF $\beta 1$ 'in tümör hücresinin migrasyonu ve invazyonunun indüklenmesi ile ilişkilendirilmesine yol açmaktadır (51). Bu nedenle, TGF $\beta 1$, malignant dönüşüm ve anjiyogeneze katılan bir metastaz indükleyicisi olarak da kabul edilmektedir $(50,52$, 53).

TGF $\beta$ 1, çeşitli dokularda kronik inflamasyonda çok önemli bir rol oynamaktadır ve epitelyalmezenkimal geçiş ve hücre dışı matriksin değişimi ile ilişkilendirilmiştir (54). MDA-MB-231 hücrelerinde TGF $\beta 1$ 'in epitelyal-mezenkimal geçiş sürecini indüklediği ve metastazı tetiklediği yapılan çalışmalarla gösterilmiştir (55-57). Elde ettiğimiz sonuçlara göre; MDA-MB-231 hücrelerinin DPKH'lerini etkileyerek TGF $\beta 1$ üretimi ve salınımını arttırdığı görülmüştür. $\mathrm{Bu}$ durum in vivo tümör ilerlemesinde, tümör mikroçevresinde bulunan tümör hücreleri tarafından etkilenerek metastatik süreci hızlandıran faktörlerin üretilmesini desteklediğini düşündürmektedir. TGF $\beta 1$ 'in, tümör ilerlemesinde önemli rolleri olan $T$ hücreleri, NK hücreleri, nötrofiller, monositler ve makrofajların anti-tümör aktivitelerini baskılaması ve tümör ilerlemesini desteklemesi de TGF $\beta 1$ 'in tümör mikroçevresinde etkili bir sitokin olduğunu göstermektedir (58).

Tang Y. ve arkadaşlarının yaptıkları çalışmada, kemik erimesi kaynaklı hasarın olduğu durumda TGF $\beta 1$ 'in ortamda artışının kemik mezenkimal kök hücrelerinin (KMKH) hasarlı bölgeye göç etme potansiyellerini arttırdığını göstermektedir. Ayrıca, kemik erimesi hasarı olan hücrelerin koşullu medyumlarında TGF $\beta 1$ 'in inhibe edilmesinin bu göçü önemli ölçüde azalttığı gösterilmiştir. Elde edilen sonuçlar kemik hasarı durumunda artan TGF $\beta 1$ sitokin seviyesinin, KMKH'lerini hasarlı bölgeye göçünü indüklediği göstermektedir (59). Çalışmamızda MDA-MB-231 hücrelerinin, DPKH'lerini etkilerek TGF $\beta 1$ sitokin seviyesini arttırdığı görülmektedir. Tümör hücrelerinin DPKH'lerinde TGF $\beta 1$ salgılanmasını indüklemesi inflamatuvar yanıtı arttırarak tümör mikroçevresine kök hücrelerin göç etme potansiyelini de etkileyecek bir ortam oluşturabileceğini akla getirmektedir.

Makrofaj İnhibitör Sitokin 1, olarak da bilinen GDF15, TGF $\beta$ ailesinin bir üyesidir $(14,60)$. GDF15'in hücre döngüsünü durdurduğu ve apoptoza yol açarak bir tümör baskılayıcı olarak 
işlev gördüğünü bildirmesine rağmen (60-62), GDF15'in pro-tümörojenik bir işleve sahip olduğunu belirten çalışmalar da bulunmaktadır $(60,61,63,64)$. Peake F. B. ve arkadaşlarının yaptıkları çalışma ile GDF15'in, MDA-MB-231 ve BT-474 hücrelerinde E-Kaderin (Epiteliyal Kaderin) ekspresyonunu arttırdığı, N-Kaderin (Nöronal Kaderin) ve Vimentin ekspresyonlarını da azaltarak epitelyal-mezenkimal geçişi ve tümör hücrelerinin invazyonunu tetiklediği gösterilmiştir (65). Çalışmamızda, MDA-MB-231 hücrelerinin, DPKH'lerini etkileyerek mikroçevreye yüksek seviyede GDF15 sitokin salgılanmasını sağlamaları, tümör hücrelerinin mikroçevreyi yeniden düzenleyerek invazyon ve migrasyon süreçlerini kolaylaştırmaya çalıştıklarını düşündürmektedir.

Yapılan çalışmalarda hem TGF $\beta 1$ 'in hem de GDF15'in tümör ilerlemesini destekleyen rolleri olduğu bilinmektedir. Ancak, bu sitokinlerin tümör mikroçevresinde artışının sebepleri tam olarak anlaşılamamıştır. Yaptığımız çalışmada MDAMB-231 hücrelerinin tümör mikroçevresini etkileyerek TGF $\beta 1$ ve GDF15 sitokin salınımlarını arttırdığı görülmektedir. Bu durumun da tümör hücrelerinin invaziv potansiyellerini arttırarak metastazı kolaylaştırabileceği öngörülmektedir. Elde ettiğimiz veriler tümör mikroçevresinde sitokin seviyelerinin değişmesinin tümöre yardımcı bir mikroçevre yarattığını göstermektedir. Çalışmamızla DPKH'leri ile meme kanseri hücrelerinin birbirlerini etkileyerek tümör mikroçevresinde değişikliğe yol açtıkları gösterildi. Bu önverilerin, tümör mikroçevresinin tümör ilerlemesi ve metastazdaki rollerinin tanımlanmasına yardımcı olacak yeni çalışmalara ışık tutacağı görüşündeyiz.

\section{SONUÇ}

Tümör mikroçevresinde bulunan hücrelerin tümör mikroçevresinin düzenlenmesindeki rollerinin araştırımasını amaçlayan çalışmamızda elde ettiğimiz sonuçlar, tümör hücrelerinin DPKH'lerini etkileyerek tümör ilerlemesi ve metastaz ile ilişkilendirilen TGF $\beta 1$ ve GDF15 sitokin salınımını artırdığını göstermektedir. Tümör mikroçevresinde artan TGF $\beta 1$ ve GDF15 seviyelerini de tümör hücrelerinin metastazlarını kolaylaştıracağı düşünülmektedir. Elde ettiğimiz bulgular, tümör hücrelerinin tümörü ilerletmeye yönelik mikroçevre oluşturduklarını işaret etmekte ve bu fikre dayanarak bulgularımızın tümör mikroçevresindeki değişimlerin daha detaylı araştırımasına dikkat çekerek yeni çalışmalara fikir oluşturacağı görüşündeyiz.

\section{TEŞEKKÜR}

Çalışmamızı destekleyen Akdeniz Üniversitesi Bilimsel Araştırma Proje Birimi'ne destekleri için teşekkür ederiz (Proje No: TSG-2020-4971).

Çıkar çatışması: Çalışmada yer alan yazarlar çıkar çatışması olmadığını kabul etmektedir.

\section{Kaynaklar}

1. Siegel RL, Miller KD, Jemal A. Cancer statistics, 2019. CA Cancer J Clin. 2019; 69 (1): 7-34.

2. Ferlay J, Soerjomataram I, Dikshit R, Eser S, Mathers C, Rebelo M, et al. Cancer incidence and mortality worldwide: sources, methods and major patterns in GLOBOCAN 2012. Int J Cancer. 2015;136 (5): E359-86.

3. Camorani S, Fedele M, Zannetti A, Cerchia L. TNBC Challenge: Oligonucleotide Aptamers for New Imaging and Therapy Modalities. Pharmaceuticals (Basel). 2018; 11 (4).

4. Nedeljkovic M, Damjanovic A. Mechanisms of Chemotherapy Resistance in Triple-Negative Breast CancerHow We Can Rise to the Challenge. Cells. 2019; 8 (9).

5. Chen F, Zhuang X, Lin L, Yu P, Wang Y, Shi Y, et al. New horizons in tumor microenvironment biology: challenges and opportunities. BMC Med. 2015;13:45.

6. Wang M, Zhao J, Zhang L, Wei F, Lian $\mathrm{Y}, \mathrm{Wu} \mathrm{Y}$, et al. Role of tumor microenvironment in tumorigenesis. J Cancer. 2017; 8 (5): 761-73.

7. Hanahan D, Coussens LM. Accessories to the crime: functions of cells recruited to the tumor microenvironment. Cancer Cell. 2012; 21 (3): 309-22.

8. Dvorak HF. Tumors: wounds that do not heal. Similarities between tumor stroma generation and wound healing. N Engl J Med. 1986; 315 (26): 1650-9.

9. Waldmann TA. Cytokines in Cancer Immunotherapy. Cold Spring Harb Perspect Biol. 2018;10 (12). 
10. Alexander WS, Hilton DJ. The role of suppressors of cytokine signaling (SOCS) proteins in regulation of the immune response. Annu Rev Immunol. 2004;22:503-29.

11. Massague J. How cells read TGF-beta signals. Nat Rev Mol Cell Biol. 2000;1(3):169-78.

12. Gordon KJ, Blobe GC. Role of transforming growth factor-beta superfamily signaling pathways in human disease. Biochim Biophys Acta. 2008; 1782 (4): 197-228.

13. Dunning AM, Ellis PD, McBride S, Kirschenlohr HL, Healey CS, Kemp PR, et al. A transforming growth factorbeta1 signal peptide variant increases secretion in vitro and is associated with increased incidence of invasive breast cancer. Cancer Res. 2003; 63 (10): 2610-5.

14. Bootcov MR, Bauskin AR, Valenzuela SM, Moore AG, Bansal M, He XY, et al. MIC-1, a novel macrophage inhibitory cytokine, is a divergent member of the TGF-beta superfamily. Proc Natl Acad Sci U S A. 1997;94 (21): 11514-9.

15. Mehta RS, Song M, Bezawada N, Wu K, Garcia-Albeniz X, Morikawa T, et al. A prospective study of macrophage inhibitory cytokine-1 (MIC-1/GDF15) and risk of colorectal cancer. J Natl Cancer Inst. 2014; 106 (4): dju016.

16. Li S, Ma YM, Zheng PS, Zhang P. GDF15 promotes the proliferation of cervical cancer cells by phosphorylating AKT1 and Erk1/2 through the receptor ErbB2. J Exp Clin Cancer Res. 2018; 37 (1): 80.

17. Corre J, Labat E, Espagnolle N, Hebraud B, Avet-Loiseau H, Roussel M, et al. Bioactivity and prognostic significance of growth differentiation factor GDF15 secreted by bone marrow mesenchymal stem cells in multiple myeloma. Cancer Res. 2012; 72 (6): 1395-406.

18. Mehta RS, Chong DQ, Song M, Meyerhardt JA, Ng K, Nishihara R, et al. Association Between Plasma Levels of Macrophage Inhibitory Cytokine-1 Before Diagnosis of Colorectal Cancer and Mortality. Gastroenterology. 2015; 149 (3): 614-22.

19. Wang T, Mao B, Cheng C, Zou Z, Gao J, Yang Y, et al. YAP promotes breast cancer metastasis by repressing growth differentiation factor-15. Biochim Biophys Acta Mol Basis Dis. 2018;1864(5 Pt A):1744-53.

20. Tran C, Damaser MS. Stem cells as drug delivery methods: application of stem cell secretome for regeneration. Adv Drug Deliv Rev. 2015; 82-83: 1-11.

21. Zhang CL, Huang T, Wu BL, He WX, Liu D. Stem cells in cancer therapy: opportunities and challenges. Oncotarget. 2017; 8 (43): 75756-66.

22. Razmkhah M, Jaberipour M, Hosseini A, Safaei A, Khalatbari B, Ghaderi A. Expression profile of IL-8 and growth factors in breast cancer cells and adipose-derived stem cells (ASCs) isolated from breast carcinoma. Cell Immunol. 2010; 265 (1): 80-5.

23. Ning $\mathrm{H}$, Lin $\mathrm{G}$, Fandel $\mathrm{T}$, Banie L, Lue TF, Lin CS. Insulin growth factor signaling mediates neuron-like differentiation of adipose-tissue-derived stem cells. Differentiation. 2008; 76 (5): 488-94.

24. Song YH, Gehmert S, Sadat S, Pinkernell K, Bai X, Matthias N, et al. VEGF is critical for spontaneous differentiation of stem cells into cardiomyocytes. Biochem Biophys Res Commun. 2007; 354 (4): 999-1003.

25. Kim WS, Park SH, Ahn SJ, Kim HK, Park JS, Lee GY, et al. Whitening effect of adipose-derived stem cells: a critical role of TGF-beta 1. Biol Pharm Bull. 2008; 31 (4): 606-10.

26. Dirat B, Bochet L, Dabek M, Daviaud D, Dauvillier S, Majed B, et al. Cancer-associated adipocytes exhibit an activated phenotype and contribute to breast cancer invasion. Cancer Res. 2011; 71 (7): 2455-65.

27. Rowan BG, Gimble JM, Sheng M, Anbalagan M, Jones RK, Frazier TP, et al. Human adipose tissue-derived stromal/stem cells promote migration and early metastasis of triple negative breast cancer xenografts. PLoS One. 2014; 9 (2): e89595.

28. Testa U, Castelli G, Pelosi E. Breast Cancer: A Molecularly Heterogenous Disease Needing Subtype-Specific Treatments. Med Sci (Basel). 2020; 8 (1).

29. Vagia E, Mahalingam D, Cristofanilli M. The Landscape of Targeted Therapies in TNBC. Cancers (Basel). 2020; 12 (4).

30. Hu M, Yao J, Cai L, Bachman KE, van den Brule F, Velculescu V, et al. Distinct epigenetic changes in the stromal cells of breast cancers. Nat Genet. 2005; 37 (8): 899-905. 
31. Soysal SD, Tzankov A, Muenst SE. Role of the Tumor Microenvironment in Breast Cancer. Pathobiology. 2015; 82 (3-4): 142-52.

32. Coleman RE, Gregory W, Marshall H, Wilson C, Holen I. The metastatic microenvironment of breast cancer: clinical implications. Breast. 2013; 22 Suppl 2:S50-6.

33. Folgueira MA, Maistro S, Katayama ML, Roela RA, Mundim FG, Nanogaki S, et al. Markers of breast cancer stromal fibroblasts in the primary tumour site associated with lymph node metastasis: a systematic review including our case series. Biosci Rep. 2013; 33(6).

34. Luster $\mathrm{AD}$, Alon $\mathrm{R}$, von Andrian $\mathrm{UH}$. Immune cell migration in inflammation: present and future therapeutic targets. Nat Immunol. 2005; 6 (12):1182-90.

35. Nagarsheth N, Wicha MS, Zou W. Chemokines in the cancer microenvironment and their relevance in cancer immunotherapy. Nat Rev Immunol. 2017;17 (9): 559-72.

36. Taniguchi K, Karin M. NF-kappaB, inflammation, immunity and cancer: coming of age. Nat Rev Immunol. 2018; 18 (5): 309-24.

37. Wang J, Li D, Cang H, Guo B. Crosstalk between cancer and immune cells: Role of tumor-associated macrophages in the tumor microenvironment. Cancer Med. 2019; 8 (10): 4709-21.

38. Young MR, Wright MA. Myelopoiesis-associated immune suppressor cells in mice bearing metastatic Lewis lung carcinoma tumors: gamma interferon plus tumor necrosis factor alpha synergistically reduces immune suppressor and tumor growth-promoting activities of bone marrow cells and diminishes tumor recurrence and metastasis. Cancer Res. 1992; 52 (22): 6335-40.

39. Ridge SM, Sullivan FJ, Glynn SA. Mesenchymal stem cells: key players in cancer progression. Mol Cancer. 2017;16 (1): 31.

40. Pittenger MF, Mackay AM, Beck SC, Jaiswal RK, Douglas R, Mosca JD, et al. Multilineage potential of adult human mesenchymal stem cells. Science. 1999; 284 (5411): 143-7.

41. Dominici M, Le Blanc K, Mueller I, Slaper-Cortenbach I, Marini F, Krause D, et al. Minimal criteria for defining multipotent mesenchymal stromal cells. The International Society for Cellular Therapy position statement. Cytotherapy. 2006; 8 (4): 315-7.

42. Gronthos S, Mankani M, Brahim J, Robey PG, Shi S. Postnatal human dental pulp stem cells (DPSCs) in vitro and in vivo. Proc Natl Acad Sci U S A. 2000; 97 (25): 13625-30.

43. Friedenstein AJ, Chailakhjan RK, Lalykina KS. The development of fibroblast colonies in monolayer cultures of guinea-pig bone marrow and spleen cells. Cell Tissue Kinet. 1970; 3 (4): 393-403.

44. Chamberlain G, Fox J, Ashton B, Middleton J. Concise review: mesenchymal stem cells: their phenotype, differentiation capacity, immunological features, and potential for homing. Stem Cells. 2007; 25 (11): 273949.

45. Sprio AE, Di Scipio F, Raimondo S, Salamone P, Pagliari F, Pagliari S, et al. Self-renewal and multipotency coexist in a long-term cultured adult rat dental pulp stem cell line: an exception to the rule? Stem Cells Dev. 2012;21(18):3278-88.

46. Hilkens $P$, Fanton $Y$, Martens $W$, Gervois $P$, Struys $T$, Politis $C$, et al. Pro-angiogenic impact of dental stem cells in vitro and in vivo. Stem Cell Res. 2014; 12 (3): 778-90.

47. Yalvac ME, Yarat A, Mercan D, Rizvanov AA, Palotas A, Sahin F. Characterization of the secretome of human tooth germ stem cells (hTGSCs) reveals neuro-protection by fine-tuning micro-environment. Brain Behav Immun. 2013; 32: 122-30.

48. Bachman KE, Park BH. Duel nature of TGF-beta signaling: tumor suppressor vs. tumor promoter. Curr Opin Oncol. 2005; 17 (1): 49-54.

49. Janda E, Lehmann K, Killisch I, Jechlinger M, Herzig M, Downward J, et al. Ras and TGF[beta] cooperatively regulate epithelial cell plasticity and metastasis: dissection of Ras signaling pathways. J Cell Biol. 2002; 156 (2): 299-313.

50. Zarzynska JM. Two faces of TGF-beta1 in breast cancer. Mediators Inflamm. 2014;2014:141747.

51. Massague J. TGFbeta signalling in context. Nat Rev Mol Cell Biol. 2012; 13 (10): 616-30. 
52. Heldin $\mathrm{CH}$, Landstrom M, Moustakas A. Mechanism of TGF-beta signaling to growth arrest, apoptosis, and epithelial-mesenchymal transition. Curr Opin Cell Biol. 2009; 21 (2): 166-76.

53. Miyazono K, Ehata S, Koinuma D. Tumor-promoting functions of transforming growth factor-beta in progression of cancer. Ups J Med Sci. 2012; 117 (2): 143-52.

54. Chen Q, Yang W, Wang X, Li X, Qi S, Zhang Y, et al. TGF-beta1 Induces EMT in Bovine Mammary Epithelial Cells Through the TGFbeta1/Smad Signaling Pathway. Cell Physiol Biochem. 2017; 43 (1): 82-93.

55. Sengupta S, Jana S, Biswas S, Mandal PK, Bhattacharyya A. Cooperative involvement of NFAT and SnoN mediates transforming growth factor-beta (TGF-beta) induced EMT in metastatic breast cancer (MDA-MB 231) cells. Clin Exp Metastasis. 2013; 30 (8): 1019-31.

56. Park HJ, Kim MK, Choi KS, Jeong JW, Bae SK, Kim HJ, et al. Neuromedin B receptor antagonism inhibits migration, invasion, and epithelial-mesenchymal transition of breast cancer cells. Int J Oncol. 2016; 49 (3): 934-42.

57. Sun Y, Zhou QM, Lu YY, Zhang H, Chen QL, Zhao M, et al. Resveratrol Inhibits the Migration and Metastasis of MDA-MB-231 Human Breast Cancer by Reversing TGF-beta1-Induced Epithelial-Mesenchymal Transition. Molecules. 2019; 24 (6).

58. Wrzesinski SH, Wan YY, Flavell RA. Transforming growth factor-beta and the immune response: implications for anticancer therapy. Clin Cancer Res. 2007; 13 (18 Pt 1): 5262-70.

59. Tang $\mathrm{Y}, \mathrm{Wu} X$, Lei W, Pang L, Wan C, Shi Z, et al. TGF-beta1-induced migration of bone mesenchymal stem cells couples bone resorption with formation. Nat Med. 2009;15(7):757-65.

60. Bauskin AR, Brown DA, Kuffner T, Johnen $\mathrm{H}$, Luo XW, Hunter M, et al. Role of macrophage inhibitory cytokine-1 in tumorigenesis and diagnosis of cancer. Cancer Res. 2006; 66 (10): 4983-6.

61. Unsicker K, Spittau B, Krieglstein K. The multiple facets of the TGF-beta family cytokine growth/differentiation factor-15/macrophage inhibitory cytokine-1. Cytokine Growth Factor Rev. 2013; 24 (4): 373-84.

62. Eling TE, Baek SJ, Shim M, Lee CH. NSAID activated gene (NAG-1), a modulator of tumorigenesis. J Biochem Mol Biol. 2006; 39 (6): 649-55.

63. Corre J, Hebraud B, Bourin P. Concise review: growth differentiation factor 15 in pathology: a clinical role? Stem Cells Transl Med. 2013; 2 (12):946-52.

64. Li C, Wang J, Kong J, Tang J, Wu Y, Xu E, et al. GDF15 promotes EMT and metastasis in colorectal cancer. Oncotarget. 2016; 7 (1): 860-72.

65. Peake BF, Eze SM, Yang L, Castellino RC, Nahta R. Growth differentiation factor 15 mediates epithelial mesenchymal transition and invasion of breast cancers through IGF-1R-FoxM1 signaling. Oncotarget. 2017; 8 (55): 94393-406. 